\title{
Teacher Accountability Using Teacher Appraisal: Perceptions of Senior High School Heads in Central Region, Ghana
}

\author{
Michael Amakyi \\ Institute for Educational Planning and Administration, University of Cape Coast \\ Cape Coast, Ghana
}

\begin{abstract}
A study using the mixed-method approach that utilized a non-experimental survey and basic interpretive designs was conducted to measure teacher accountability through teacher appraisal. Closed-ended Likert-type questionnaire and semi-structured interview protocol were used to collect data from the study respondents consisting of heads of senior high schools in Central region of Ghana. Data collected were analyzed using descriptive statistics and identification of emerging themes. Major findings reported in the study were that respondents adopted a systematic and organized approach that allows for the setting of achievable goals and development of blueprint to conduct teacher appraisal. The use of teacher appraisal is restricted to facilitate mainly the managerial duties of the school head with little attention focused on teacher growth and development. A key recommendation was that school heads should align teacher appraisal with the strategic goals of the school improvement plan.
\end{abstract}

Keywords: Teacher accountability, Teacher Appraisal, Teacher development, Learning outcomes

DOI: $10.7176 / \mathrm{JEP} / 12-29-09$

Publication date:October $31^{\text {st }} 2021$

\section{Introduction}

Schools are set up to provide education that is fit for purpose to enable society pursue continuous development and growth. The broad goals of schools are directed at providing students with opportunities to solve intellectual problems and use higher cognitive abilities. The education provided by schools should produce the calibre of students who will have the competence needed to not only survive, but to impact their society by acquiring the knowledge, skills, and abilities to productively function in the society, while effectively addressing any emerging personal and social needs. Schools are thus expected graduate citizens who will live life to the fullest; that is, to transform learners to become good citizens and at the same time equip them with the requisite knowledge to contribute to the economic growth and development of the nation.

Various stakeholder groups (e.g., school boards, management, teachers, ancillary school staff, parents, school community, learners) bear the responsibility and are held accountable to ensure that school processes lead to the attainment of the goals of education. School processes refer to the set of activities carried out in a school by the stakeholders and these include programmes, designing and implementing curriculum, adopting learner-centred instructional pedagogies, utilizing appropriate assessment strategies, carrying out innovative interventions, and putting in place related school practices that facilitate teaching and learning (Amakyi, 2017). Acknowledging the important role played by the various stakeholder groups and while not downplaying the contribution of any group in facilitating teaching and learning, Rice (2003) points to teachers as critical stakeholder factor influencing student achievement. It is the activities of teachers who adopt and adapt innovations to respond to the needs of their learners in the classrooms that define student achievement. Fullan and Hargreaves (2016) agree with Rice and state that teachers lie at the heart of the provision of instructional quality teaching in the classroom and they drive learners' success in education. Murati (2015) points out that the teacher as a relevant factor in successfully achieving educational process is an undeniable statement, drawing attention to the role of the teacher in the educational process. According to Murati (2015), teachers possess the professional ability acquired through their training and preparation to plan, organize, and carry out work on student learning.

Block, Crochet, Jones, and Papa (2012) observe that heightened emphases on teachers and effective teaching that is linked to the performances of learners puts into perspective a focus on teacher accountability in the education process. Cantrell and Kane (2013) postulate that the instructional teaching quality of the teacher in the classroom has a strong predictive validity of students' learning progress. Various authors (e.g., Dulay \& Karadag, 2017; Roorda, Koomen, Spilt, \& Oort, 2011) add another dimension to explain the heightened interest in teacher accountability in the school. The authors note that aside the traditional role of delivering the lesson, the quality of teacher-student-relationships impact student achievement.

The positive link between teacher-student relationships and students' social-emotional well-being that ultimately affect student learning is given credence by Chory and Offstein (2018) and Dietrich and Cohen (2019) who opine that positive teacher-student relationships have ripple effects and the relationships indirectly improve students' emotional well-being. Dietrich and Cohen (2019) posit that how teachers treat students affects how 
students treat each other.

The primary responsibility of teachers translated into their designated duties, flow out of their job descriptions and job specifications. These job descriptions and job specifications provide the frame within which the expectations and standards of operation are communicated to the teachers. In other words, they spell out the intended work output of teachers. Thompson and Strickland (2007) state that maximizing staff performance is a priority for organizations and hence the output of the staff will have to be measured. A way to maximize teacher performance is to ascertain if there is alignment of teacher performance with the stated expectations and standards. Teacher appraisal is the means adopted by schools to assure for such alignment. According to Akinyele (2010), teacher appraisal is a systematic way of reviewing and measuring the performance of teachers and adopting the findings of the appraisal to plan for improving performance in the future. Teacher appraisal thus provides the school with the platform to examine and evaluate teacher work output and attitude comparing them with preset standards. It is an opportunity for the school's operations to be aligned with its stated mission and goals with a focus on the daily activities of teachers (Armstrong, 2008). Teacher appraisal reviews the performance of teachers to establish if there is a gap between prescribed and described teacher behavior leading to differences in the actual and the desired teacher performance. Conducting teacher appraisal in schools facilitates the assurance of teacher accountability for tasks entrusted to them. Teacher appraisal can therefore be viewed as assessing teacher job related task accomplishments or failures. Grote (2002) observes that the process for conducting teacher appraisal enables an institution to organize and coordinate the power of every teacher towards the achievement of its strategic goals by focusing each teacher's mind on the mission and vision of the school.

Teacher appraisal is a process where designated persons in the school, usually the school head, evaluates teachers and provide feedback on their job performance. Teacher appraisal can be seen as the systematic evaluation of the performance of teachers with the aim to reflect back to the teachers how a teacher is meeting performance expectations at the workplace with the intention to provide support for improved performance. According to Price (2011), teacher appraisal is a periodical advisory and support discussions between teachers and school heads that foster agreements about objectives and the achievement of targets, which can be incorporated into target agreements. Price further notes that the process of teacher appraisal provides the opportunity in a more formal way to discuss matters that support and advance target-oriented cooperation. Price is of the opinion that through teacher appraisal constructive discussion of teacher performance is fostered which leads to the identification of possible areas for development, including suggested approaches to accomplish this (e.g., through individual develop plan).

Staff appraisal is seen as a process which involves an interchange on job attainment between staff and supervisor over a specified period. Such a period is set usually to be one year. Huber and Skedsmo (2016) note that staff appraisal is not about a single event, such as, completing a standard review form, but rather a process that is on-going and unending and which focuses on staff improvement and goal attainment.

Teacher appraisal does not just occur on its own; it has to be orchestrated and coordinated through the adoption of specific methods. behaviorally anchored rating scales The attributes rating methods, comparative methods, behaviorally anchored rating scales, management by objectives, and written (narrative) methods can be adopted to conduct teacher appraisal. In the attributes rating methods, the appraiser rates an employee's level of performance on a specific form (work standard) using rating scales. The rating scales consist usually of a set of categories defined by descriptive labels of employee attributes and presented in clear progression of response choices (Donaldson, 2013). The rating scales require an appraiser to indicate on a scale the degree to which an employee demonstrates a particular trait, behaviour, or performance result. Each scale is a continuum of scale points, which range from low to high or from poor to good.

With the comparative methods, the appraisers directly compare performances of their employees against one another using ranking (i.e., ranks employees in a group from the worst to the best performers), paired comparison (i.e., compares each employee with every other employee in a rating group at a time), and forced distribution (i.e., distributes the employees on all points on a scale to conform performance to a normal distribution) (Aggarwal \& Thakur, 2013). The behaviorally anchored rating scales consist of statements of effective and ineffective behaviours represented on a continuum of descriptive statements of behaviors ranging from least to most effective; and the appraiser selects which behavior describes the employee's performance (Khanna \& Sharma, 2014).

The adoption of the management by objectives method entails the setting of strategic goals to be attained and employee performance measured against these strategic goals (Ntanos \& Boulouta, 2012). A check list is usually used to measure employee performance, however, the adoption of interview is not ruled out.

The written or narrative methods entails the use of short essays to describe each employee's performance under assigned headings. This may take the form of the appraiser keeping records of significant incidents that occur in the course of the employee performing assigned duties and the behavior (including the attitudes, emotions, skills, knowledge, and resources) manifested by the employee. Another form of the written method is 
the use of free essay where the appraiser offered the opportunity to describe the employee in detail within defined categories spanning across existing capabilities and qualifications of performing jobs, strengths and weaknesses, and training needs of the employee (Khanna \& Sharma, 2014).

Teacher appraisal provides a link between teacher responsibility and accountability. Teacher appraisal enables organizations to assess if there is alignment between teacher responsibility and accountability. It is through assigned responsibility that teachers get to know what the school wants them to do in terms of performance. Teacher responsibility provides clarification on what the job entails, the procedures to be followed in executing the job, and the requisite training and development needs of the teacher to execute the job. In assuring accountability, teacher appraisal offers teachers the platform to be answerable for their actions and demonstrate the extent to which responsibilities entrusted to them have been carried out. Accountability in teacher appraisal provides assurance to the public that professional incompetence and malpractice will be detected and corrected. The alignment between responsibility and accountability provides the impetus for individual staff growth and school improvement. The immediate target for conducting teacher appraisal is to improve individual teacher performance in the school. However, when that is achieved, overall school improvement will follow suit.

\section{Problem Statement and Research Questions}

Authors such as Armstrong (2008) and Brown and Heywood (2005) conclude that the intended outcome of staff appraisal is to assess strengths, determine competence, and to provide support and mentoring to guide the longterm career goals of the staff in order to enhance staff efficiency. Teacher appraisal is designed to have a developmental purpose that is directed towards enhancing the capacity of teachers for improved performance. Teacher appraisal is to serve as opportunity for teachers to adopt best practices by building on and complementing their previous positive behaviours to improve their performance.

School heads of senior high schools in the Central region, Ghana conduct annual teacher appraisal as an integral part of their managerial duties. The annual teacher appraisal is intended to evaluate teachers and provide feedback on their job performance. The conduct of teacher appraisal is twofold. First, to determine how well teachers do their assigned duties in relation to teacher professional standards and job specifications to facilitate learning among students. Second, to provide feedback to teachers on their performance to aid their continuing improvement and progress. Conducting teacher appraisal has been a functional responsibility of school heads over the years, however, it gained prominence in the early $90 \mathrm{~s}$ when school heads started to put more emphasis on school improvement and identified teacher appraisal as a strong correlate of teacher improved performance (Kowalski, 2017). According to Elliott (2015), a key success factor for conducting teacher appraisal is stakeholders' understanding of the process and intended outcomes. Such understanding shapes the perception of what constitutes success. As a tool to evaluate teacher effectiveness, is the conduct of teacher appraisal rule driven or mission driven? Also, Mollel, Mulongo and Razia (2017) state that teacher appraisal is an evaluation of teacher performance and the success of the appraisal is the potential of the process resulting in improving teacher future performance. Does teacher appraisal result in improved teacher performance? Data to enable the questions posed to be adequately addressed are not readily available. While there are records showing that teacher appraisal has been conducted, there is dearth of documentary evidence to show the successes chalked in conducting teacher appraisal in schools. The absence of data on how school heads perceive successes of the implementation of teacher appraisal in schools was the driving force for this study. The overarching purpose of this study was to measure teacher accountability using successes chalked in teacher appraisal as perceived by school heads. Findings from this study will help school heads in their review of how teacher appraisal is conducted. The study was guided by the following research questions:

1. How is teacher appraisal conducted in schools?

2. What are the perceptions of school heads about the successes of teacher appraisal in schools?

3. How is teacher appraisal utilized as perceived by school heads to address teacher accountability?

\section{Research Methods}

The non-experimental survey and a basic interpretive designs were adopted for the study. The non-experimental survey design is a very valuable tool for assessing perceptions, opinions and trends. Even on a small scale, assessing and evaluating opinion with carefully designed surveys can surface in-depth information. In this study, the researcher sought the perceptions of school heads about successes attained in conducting teacher appraisal in schools. The utilization of the non-experimental survey design enabled the researcher to get responses from wider participant population who would provide information on the successes of teacher appraisal without the application of any intervention to the independent variables. Basic interpretive study is helpful in understanding a phenomenon and the perspectives of the people involved and how they construct their worlds, as well as the meaning they attribute to their experiences.

The study population consisted of school heads of accredited public senior high schools in Central region, Ghana $(\mathrm{N}=76)$. Census was employed as the sampling technique to gather data for the survey. According to 
Sarantakos (2005), census method is when the total population is the same as the sample size. Sarantakos states that a census is an attempt to list all elements in a group and to measure one or more characteristics of those elements. The results obtained from census method have high accuracy as each member is surveyed. The instrumentation used for the study was made up of a semi-structured interview protocol and 24 closed-ended items. The semi- structured interview protocol was used to elicit information from 10 purposefully-selected school heads, five of whom have spent at least three years in office and the other five have spent less than three years in office. Literature on staff appraisal served as the primary source for the development of the questionnaire items. The statements on the questionnaire elicited responses from the school heads in the following categories, (a) teacher appraisal implementation in schools, (b) successes of teacher appraisal, and (c) utilization of teacher appraisal for teacher accountability. The first part of the questionnaire elicited responses from school heads on teacher appraisal implementation. The school heads selected from the four response choices: seldom; sometimes; often; and always and coded as "I", "2", "3", and "4" respectively to address research question one. To address the research question one, how is teacher appraisal conducted in schools? The items on the questionnaire allowed the school heads to select more than one method, if that indicated how appraisal was conducted. The decision rule to interpret the response choices on a continuous scale was as follows: $1.0 \leq \mathrm{M}<1.5$ : Seldom

$1.5 \leq \mathrm{M}<2.5$ : Sometimes

$2.5 \leq \mathrm{M}<3.5$ : Often

$3.5 \leq \mathrm{M} \leq 4.0$ : Always

The second part of the questionnaire elicited responses from school heads on successes and utilization of teacher appraisal for teacher accountability. The responses to the questions were selected from one of four response choices: strongly disagree, disagree, agree, and strongly agree to address research questions two and three. The response choices were coded as: strongly disagree $=1$, disagree $=2$, agree $=3$, and strongly agree $=$ 4.

The survey instrument was distributed in person to the school heads with the help of research assistants. The final number of returned surveys used for the data analyses was $n=63$, constituting a response rate of about $80 \%$. The data collected were analyzed using means and standard deviations. The interview data were analyzed and put into themes that provided descriptions to further research questions two and three.

\section{Findings and Discussions}

The respondents indicated which of the appraisal methods school heads frequently adopt to address research question one, how is teacher appraisal conducted in schools? The respondents selected from the four response choices: seldom; sometimes; often; and always. First, means and standard deviations were calculated for the responses to each item and rank ordered. The results of the ranked-ordered computed means and standard deviations are shown in Table 1.

Table 1 Rank-ordered means for appraisal method

\begin{tabular}{lll}
\hline Appraisal Method & Mean & Standard Deviation \\
\hline Attributes rating & 3.73 & 0.79 \\
Behaviorally anchored rating scale & 3.52 & 0.78 \\
Comparative & 2.24 & 0.77 \\
Essay & 2.10 & 0.66 \\
Management by objectives & 1.23 & 0.50
\end{tabular}

The respondents identified the Attributes Rating (work standard approach) and the "Behaviorally Anchored Rating Scale" as the two methods that were in use as appraisal methods in the schools. This finding is consistent with the research of various authors (e.g., Mathis \& Jackson, 2011; Mullins, 2007; Huber \& Skedsmo, 2016). According to Mathis and Jackson (2011), institutions do not adopt a one size fits all approach when it comes to selecting appraisal method. They tend to use more than one appraisal method. Ntanos and Boulouta (2012) point out that institutions that place high premium on quality delivery tend to use the Attributes Rating approach, which is a systematic and organized approach that allows for the setting of achievable goals and development of blueprint to attain the best possible results from available resources. Armstrong (2012) postulates that the Behaviorally Anchored Rating Scale has gained popularity in its usage for staff appraisal specifying performance factors and often used concurrently with the Attributes Rating approach (Boachie-Mensah \& Seidu, 2012). Again, the finding that the Management by Objectives approach is seldom in use as an appraisal approach in the schools supports the postulates of Nickols (2007). According to Nickols, Management by Objectives approach is not suitable for job designs that are fixed in nature and those done by teams, such as teaching, since it is not easy to isolate the contributions of individual team members in order to determine whether or not they achieved the set objectives.

Respondents indicated the extent of agreement or disagreement with statements about successes attained with teacher appraisal in schools to address research question two, what are the perceptions of school heads 
about the successes of teacher appraisal in schools? Group means and standard deviations were computed from respondents' selected choices of strongly disagree, disagree, agree, and strongly agree. The adopted decision rule used to interpret the computed means was as follows:

$\mathrm{M} \leq 1.5$ indicates strong disagreement with statement

$1.5<\mathrm{M} \leq 2.5$ indicates disagreement with statement

$2.5<\mathrm{M} \leq 3.5$ indicates agreement with statement

$3.5<\mathrm{M} \leq 4.0$ indicates strong agreement

The results of the computed means for the broad groups are depicted in Table 2.

Table 2 Means of successes of teacher appraisal

\begin{tabular}{lll}
\hline Success of teacher appraisal implementation & Mean & Std. Deviation \\
\hline Appropriate process adopted for teacher appraisal & 1.47 & 0.91 \\
Establishing clearly the rationale for teacher appraisal & 3.69 & 0.87 \\
Scheduled timing adhered to for teacher appraisal & 1.89 & 0.72 \\
Targeted participants are included in teacher appraisal & 3.60 & 0.93 \\
Relevant activities conducted for teacher appraisal & 2.95 & 0.55 \\
\hline
\end{tabular}

The respondents indicated strong agreement with the sub-dimensions, establishing clearly the rationale for teacher appraisal $(\mathrm{M}=3.69 . \mathrm{SD}=0.87)$ and targeted participants are included in teacher appraisal $(\mathrm{M}=3.60$, $\mathrm{SD}=0.93)$ as successes achieved in teacher appraisal. The findings are consistent with the works of various authors (e.g., Darling-Hammond, Amrein-Beardsley, Haertel, \& Rothstein, 2012); Elliott, 2015; Islami, Mulolli, \& Mustafa, 2018; Kowalski, 2013) who posit that establishing rationale for teacher appraisal provides understanding of why the appraisal is being conducted. Effective appraisal is based on unambiguous statements on established standards and 'why' the appraisal is being conducted. For example, according to Kowalski (2013), a crucial hurdle to overcome in conducting teacher appraisal is to eliminate suspicions on the part of teachers. Establishing rationale and communicating same to teachers help to gain teacher active participation teacher. Clearly stating the rationale to conduct teacher appraisal is key in setting boundaries for the appraisal and assuring teacher participation; a necessary and sufficient foundation for programme implementation (Darling-Hammond et al., 2012). When the rationale is clearly stated, a clear picture of what has to be done is provided (Teasley, 2017).

Also, the finding that targeted participants are included in teacher appraisal as success is congruent with the findings of Buckingham and Vosburgh (2001) and Mollel, Mulongoand, and Razia (2017). The authors opine that the measure of success in implementing staff appraisal lies with identifying the group whose performance is being measured and establish a linkage to increased teacher productivity.

However, the respondents identified two sub-dimensions, appropriate process adopted for teacher appraisal $(\mathrm{M}=1.47, \mathrm{SD}=0.91)$ and scheduled timing adhered to for teacher appraisal $(\mathrm{M}=1.89, \mathrm{SD}=0.72)$ that they indicated a strong disagreement as being successes in teacher appraisal. This finding is at variance with the seminal works of Armstrong (2012), Hallinger, Heck, and Murphy (2014), Creamer and Janosik (2008) and LeVan (2017) that define staff appraisal items as based on prescriptions of how processes should be done. The authors agree that success in teacher appraisal is based on clearly specified ways of conducting appraisal in terms of stages. According to Hallinger et al. (2014), teacher appraisal should involve pre-appraisal meeting and feedback session. The authors point out that the pre-appraisal meeting will establish performance indicators and the feedback session will identify areas that need strengthening and improvement. Armstrong (2012) notes that teacher appraisal process should be a planned activity with performance targets and output meeting the criteria of being specific, measurable, achievable, realistic and time bound.

Two major themes, confidence of teachers in the appraisal instrument and participation in appraisal process, emerged when a further inquiry into perceptions of successes of teacher appraisal through the semistructured interviews was conducted with selected informants. First, the informants mentioned that the appraisal document was consistently utilized; each teacher received basically the same appraisal document.

A study informant stated:

I am happy that the appraisal document remains the same across board for all the teachers. Every teacher goes through the same document. There is consistency in what I do.

Majority of the informants stated:

Using the same document assures us of unbiasedness and believe

that this increases the confidence of the teachers in the process.

Another informant intimated:

there was no room to be accused of favoritism in the process.

All teachers received the same document and this enabled us

to carry out our responsibility with peace of mind.

Second, majority of the informants indicated that because the purpose of the appraisal was explained to the 
teachers, the teachers showed willingness to participate in the appraisal process.

An informant indicated: we do not encounter resistance from the teachers to participate in the appraisal process. Once we have explained the intended outcome of the process, the teachers participate fully.

Another informant shared:

I do not hear grumbling on the part of teachers and they do not also make excuses to avoid taking part in the exercise. The entire exercise is conducted in an atmosphere devoid of threats or use of power to coerce teachers to take part.

To address research question three, how is teacher appraisal utilized as perceived by school heads to address teacher accountability? Means and standard deviations were computed from the frequency counts of the responses of the participants. The means were rank-ordered from highest to the lowest. Data pertaining to the rank-ordered means for how teacher appraisal is utilized are shown in Table 3.

Table 3 Rank-ordered means for teacher appraisal utilization

\begin{tabular}{lcc}
\hline Teacher appraisal utilization & Mean & Std. Deviation \\
\hline Improves supervision in school & 3.68 & .51 \\
Clarifies teacher job description & 3.61 & .82 \\
Provides documentation for teacher promotion & 3.58 & .55 \\
Identifies teachers' strengths and weaknesses & 2.71 & .48 \\
Provides information about needs of teachers & 2.66 & .87 \\
Supports improvement of teacher pedagogical skills & 2.65 & .55 \\
Generates information for school improvement & 2.56 & .34 \\
Serves as a tool for teacher personal development & 2.33 & .67 \\
Provides guidelines for teacher involvement & 2.25 & .54 \\
Provides input for teacher compensation packages & 1.98 & .21 \\
\hline
\end{tabular}

Based on Table 3 and the previously established decision rule, respondents identified three statements, improves supervision in school $(\mathrm{M}=3.68, \mathrm{SD}=.51)$, clarifies teacher job description $(\mathrm{M}=3.61, \mathrm{SD}=.82)$, provides documentation for teacher promotion $(\mathrm{M}=3.58, \mathrm{SD}=.55)$, they are in strong agreement with on how teacher appraisal is utilized. The three areas form part of the managerial duties of the school head. This finding suggests that respondents utilize teacher appraisal in carrying out their basic managerial duties. Various authors, Darling-Hammond, Amrein-Beardsley, Haertel, and Rothstein (2012); Elliott (2015), Hallinger, Heck, and Murphy (2014); Jacobson and Battaglia (2003), see the utilization of teacher appraisal as more than carrying out the managerial duties of the school head. For example, Jacobson and Battaglia (2003) opine that appraisal should be natural, systemic part of the life-long learning of a teacher. The utilization of appraisal includes a focus on teacher growth. Similarly, Hallinger et al. (2014) note that teacher appraisal can be used to attain teaching effectiveness by strengthening the quality of teaching through the provision of feedback for professional reflection and professional development planning. Teacher appraisal utilization is thus not restricted to supporting the school head to discharge duties, but it is used in different areas to support school improvement efforts in general and improve teaching and learning in particular.

The findings also showed that the respondents were in disagreement with the statements that teacher appraisal was utilized to serve as a tool for teacher personal development $(\mathrm{M}=2.33$, $\mathrm{SD}=.67)$, provide guidelines for teacher involvement $(\mathrm{M}=2.25, \mathrm{SD}=.54)$ and provide input for teacher compensation packages $(\mathrm{M}=1.98, \mathrm{SD}=.21)$. The study findings are at variance with the seminal works of several authors, notable among them are Darling-Hammond (2013); Mollel, Mulongo and Razia (2017); Mullins (2010); Papay (2012); and Rebore (2014). The authors agree that the primary utilization of appraisal is towards the professional growth of the teacher. The appraisal information is to serve as a basis for modifying or changing behavior toward more effective pedagogical habits. For example, Mollel, Mulongo and Razia (2017) identify human resources as the most valuable assets in an institution and postulate that when their needs are adequately met, they can contribute significantly to increase institutional effectiveness. Papay (2012) holds the view that educational authorities can use the appraisal information to hold teachers accountable and reward high-performing teachers and remove those who do not meet the required standards.

Again, further enquiry about how teacher appraisal is used showed that the school heads have restricted usage of the results of the appraisal process. Majority of the informants mentioned that teacher appraisal is used to help their work, more specifically, to inform what they write in their confidential report about teachers.

An informant stated:

I want to be fair to my teachers and so I conduct the appraisal and use the results for their report. The results speak for themselves. I am sure in the absence of the appraisal results, some teachers 
may be quick to level accusations of favoritism against me or they may point to being victimized if they get an unfavorable report.

Several informants remarked:

Teacher appraisal is supposed to be conducted annually, but it is not faithfully done. However, I do it when it is time for the teacher to be promoted. I use the teacher appraisal to guide my decisions to recommend a teacher or not for promotion.

Other informants stated:

The only time I use the appraisal results is when I have to appoint

a teacher to a position or when I have to select a teacher for an

assignment and I am not sure of who to select.

According to Mullins (2010), appraisal is used to make judgments for compensation packages, for example, merit pay increase and promotion. However, the informants noted that they seldom use appraisal for compensation packages.

An informant stated:

compensation packages are determined by a different body

(Parent Teacher Association) that set their criteria across board for

the teachers. I do not use the appraisal results to provide input.

I have very little to do with such compensation packages.

\section{Conclusion and Recommendations}

Teacher appraisal is intended to provide vital information to promote teacher effectiveness that will drive improved teaching and learning in the school. Based on the findings, this study draws the conclusion that teacher appraisal as a tool to assure teacher accountability and school improvement efforts is not being exploited to its fullest potential. The use of teacher appraisal is restricted to facilitate mainly the managerial duties of the school head with little attention focused on teacher growth and development. Teacher appraisal successes are achieved with the processes of establishing clearly the rationale for teacher appraisal and having targeted participants included in the conduct of the appraisal. Based on the findings and conclusion, the following recommendations are made:

1. the school heads should explore and access the full benefits of teacher appraisal and incorporate the appraisal process into the school's calendar.

2. the school heads should align teacher appraisal with the strategic goals of the school improvement plan.

3. this study focused on the perceptions of school heads about successes in conducting staff performance appraisal. This topic needs to be explored with teachers as the respondents to generate comprehensive information of teacher appraisal for decision making.

\section{References}

Aggarwal, A., \& Thakur, G. S. M. (2013). Techniques of performance appraisal-a review. International Journal of Engineering and Advanced Technology (IJEAT), 2(3), 617-621

Akinyele, T. S. (2010). The influence of work environment on workers productivity: A case of selected oil and gas industry in Lagos, Nigeria. African Journal of Business Management 4(3):299-307

Amakyi, M. (2017). School improvement: Strategies for effective change. Accra, Ghana: Datro \& Wrenco.

Armstrong, M. (2012). Armstrong's handbook of Strategic Human Resource Management (5th ed.). London: Kogan Page

Kowalski, T. (2010). The school principal: visionary leadership and competent management. New York: Routledge

Kowalski, T. (2013). The school superintendent: Theory, practice, and cases (3rd ed). Thousand Oaks, CA: Sage Publishing

Block, E., Crochet, F., Jones, L., \& Papa, T. (2012). The importance of teacher's effectiveness. Creative Education, 3, 1164-1172.

Boachie-Mensah, F.O. \& Seidu, P. (2012). Employees' perception of performance appraisal system: A case study. International Journal of Business \& Management, 7(2), 73-88.

Brown, M., \& Heywood, J. S. (2005). Performance appraisal systems: Determinants and change. British Journal of Industrial Relations, 43 (4), 659-679

Buckingham, M., \& Vosburgh, R. M. (2001). The 21st century human resources function: It's the talent, stupid! Human Resource Planning, 24(4), 17-23.

Rice, J. (2003). Teacher quality: Understanding the effectiveness of teacher attributes. Washington, DC: Economic Policy Institute.

Cantrell, S., \& Kane, T.J. (2013). Ensuring Fair and Reliable Measures of Effective Teaching: Culminating 
Findings from the MET Project's Three-Year Study. Seattle, Washington: Bill \& Melinda Gates Foundation, Policy and Practice Brief, Measures of Effective Teaching project.

Chory, R. M., \& Offstein, E. H. (2018). Too close for comfort? Faculty-student multiple relationships and their impact on student classroom conduct. Ethics \& Behavior, 28(1), 23-44.

Darling-Hammond, L. (2012). The right start: Creating a strong foundation for the teaching career. Phi Delta Kappan, 94 (3), 8-13.

Darling-Hammond, L., Amrein-Beardsley, A., Haertel, E., \& Rothstein, J. (2012). Evaluating teacher evaluation. Phi Delta Kappan, 93 (6), 8-15.

Dietrich, L., \& Cohen, J. (2019). Understanding classroom bullying climates: The role of student body composition - relationships, and teaching quality. International Journal of Bullying Prevention. Retrieved on August 1, 2021 from doi:10.1007/s42380-019-00059-x

Donaldson, M. L. (2013). Principals' approaches to cultivating teacher effectiveness constraints and opportunities in hiring, assigning, evaluating, and developing teachers. Educational Administration Quarterly, 49(5): 838-882.

Dulay, S., \& Karadağ, E. (2017). The effect of school climate on student achievement. In E. Karadağ (Ed), The factors effecting student achievement (pp. 199-213). Cham, Switzerland: Springer International Publishing

Elliott, K. (2015). Teacher Performance Appraisal: More about Performance or Development? Australian Journal of Teacher Education, 40(9), 12 - 19

Fullan, M., \& Hargreaves, A. (2016). Bringing the profession back in: Call to action. Oxford, OH: Learning Forward.

Grote, R. C. (2002). The performance appraisal question and answer book: A survival guide for managers. New York: American Management Association

Hallinger P., Heck, R. H., \& Murphy, J. (2014). Teacher evaluation and school improvement: an analysis of the evidence. Educational Assessment, Evaluation and Accountability, 26(1), 5- 28.

Huber, S.G., \& Skedsmo, G. (2016). Teacher evaluation: Accountability and improving teaching practices. Educational Assessment, Evaluation and Accountability, 28, 105-109. Retrieved on August 1, 2021 from https://doi.org/10.1007/s11092-016-9241-1

Islami, X., Mulolli, E., \& Mustafa, N. (2018). Using management by objectives as a performance appraisal tool for employee satisfaction. Future Business Journal, 4(1), 94-108

Jacobson, S. L., \& Battaglia, C. F. (2001). Authentic forms of teacher assessment and staff development in the US. In D. Middlewood and C. Cardno, Managing teacher appraisal and performance: A comparative approach (pp. 75 -90). New York: RoutledgeFalmer

Khanna, M., \& Sharma, R. K. (2014). Employees performance appraisal and its techniques: a review. Asian Journal of Advanced Basic Sciences, 2 (2), 51-58

LeVan, K. B. (2017). Examining the relationships between performance appraisal reactions and employee engagement. Human Resource Development Theses and Dissertations. Paper 18. Retrieved on August 1, 2021 from http://hdl.handle.net/10950/558

Mathis, R. L., \& Jackson, J. H. (2011). Human resource management: Essential perspectives (6th ed.). Boston: Cengage Learning

Mollel E. R., Mulongo L. S. \& Razia M. (2017). The influence of performance appraisal practices on employee productivity: A case of Muheza District, Tanzania. Issues in Business Management and Economics, 5(4), 45-59.

Mullins, L. (2007). Organisational behaviour (4th ed). New York: Pearson Education

Mullins, L. (2010). Management and organizational behavior (9th ed.). New York: Prentice Hall

Murati, R. (2015). The role of the teacher in the educational process. The Online Journal of New Horizons in Education, 5, 2. Retrieved on August 1, 2021 from https://www.tojned.net/journals/tojned/articles/v05i02

Nickols, F. (2007). Performance appraisal: Weighed and found wanting in the balance. Journal for Quality \& Participation, 30(1), 13-16.

Ntanos, A. S., \& Boulouta, K. (2012). The management by objectives in modern organisations and enterprises. International Journal of Strategic Change Management, 4 (1), 68-79

Papay, J. P. (2012). Refocusing the debate: Assessing the purposes and tools of teacher evaluation. Harvard Educational Review, 82(1), 123-141.

Price, A. (2011). Human resource management (4th ed.). Boston: Cengage

Rebore, R. (2014). Human resources administration in education (10th ed). New York: Pearson

Sarantakos, S. (2005). Social Research (3rd ed). New York: Palgrave Mac-Millan.

Teasley,M. L. (2017). Organizational culture and schools: A call for leadership and collaboration. Children \& Schools, 39 (1), 3-6

Thompson, A. A. \& Strickland, A. J. (2007). Strategic management: Concepts and Cases. California: McGrawHill/Irwin 